\title{
THE ORIGIN OF MID VOWELS IN SIWI
}

\author{
Lameen Souag \& Marijn van Putten ${ }^{1}$ \\ LACITO (CNRS - Paris 3 - INALCO)
}

\begin{abstract}
Recent documentation has established that the Siwi language of western Egypt, unlike most other Berber languages, has two phonemic mid vowels appearing not only in Arabic loanwords but also in inherited vocabulary: /e/ and /o/. This article examines their origin. Proto-Berber originally had a single mid vowel $*$ e, which appears to have been retained in Siwi only before word-final $/ \mathrm{n} /$. In all other environments the contrast between $* \mathrm{i}$ and $*_{\mathrm{e}}$ has been neutralized, although word-finally this contrast seems to have survived into the 19 th century. Instances of /e/ in other environments are phonetically conditioned, deriving variously from $* \mathrm{i}, * a \mathrm{a} y$, or $* a \mathrm{a}$ in appropriate contexts. The few attestations of $/ \mathrm{o} /$ are irregular, but occur in environments paralleling those in which /e/ is attested synchronically. Modern Siwi mid vowels are thus mostly secondary developments; except in final /-en/, they provide no direct evidence for the reconstruction of mid vowels in earlier intermediate stages of Berber.
\end{abstract}

Keywords: Siwi, Berber, phonology, vowels

\section{Introduction}

Most Berber languages have a vowel system consisting of /a/, /i/, /u/ plus /ə/. Some varieties, however, additionally display mid vowels /e/ and/or/o/. Insofar as these vowels appear in inherited vocabulary, their origin poses difficulties: Are they inherited from proto-Berber, or do they derive from later secondary developments? Students of Berber have traditionally assumed the three vowel plus schwa system to be original. However, Prasse (1990) has argued that /e/ existed in proto-Berber and has been preserved as such in Tuareg and in Ghadames, while /o/ did not. Recent documentation of Ghomara Berber (El Hannouche 2008, Mourigh forthcoming) has opened up the possibility that the reflexes of $*_{e}(>a)$ and $*_{i}$ also remain distinct there, strengthening the case for its antiquity.

In Siwi, the Berber language of Siwa in western Egypt, both /e/ and /o/ are phonemically distinct from /i/ and /u/, as first observed by Vycichl (1981:176, 2005:180) and established by Naumann (2012: 272-273, 303-307). They occur in inherited vocabulary as well as loans. Naumann suggests, "The mid vowels /e, o/ seem to have acquired phonological status only recently in Siwi", noting that they are "most typically found in final CVC syllables", but makes no attempt to explain their emergence (2012:272-273). Vycichl (2005:189) proposes derivations for two morphemes with /e/, but makes no attempt to establish regular correspondences involving this vowel. Souag (2013:35) suggests diphthong coalescence and vowel harmony as sources for Siwi

1 The first author acknowledges the support of LACITO during this article's preparation, and of the Arts and Humanities Research Council during earlier doctoral fieldwork which provided much of the data used here. Both authors thank the Siwis whose kind help made this research possible, and thank Maarten Kossmann and anonymous reviewers for comments on an earlier draft of this paper. 
mid vowels, but does not demonstrate this or work out the details. The origin of Siwi mid vowels therefore remains an open question. This paper will show that Siwi has preserved the $* e$ reflected in Tuareg and Ghadames only before word-final $n$; otherwise, it has innovated /e/ and /o/ through a "conspiracy" of several distinct sound changes.

Unless otherwise stated, all Siwi data cited here derives from Souag (ms), a draft lexicon of about 3500 words; forms from Naumann (ms) are specifically cited as such. For other Berber languages, the sources unless otherwise indicated are: Van Putten (2014) and Paradisi (1960a;b) for Awjila; Paradisi (1963) for El-Fogaha; Benamara (2013) for Figuig; Lanfry (1973) for Ghadames; Dallet (1982) for Kabyle; Mourigh (forthcoming) for Ghomara; Oussikoum (2013) for Middle Atlas; Beguinot (1942) for Nefusi; Delheure (1987) for Ouargla; Sarnelli (1924) for Sokna; Prasse et al. (2003) for Tamajeq; Heath (2006) for Tamasheq; Boudot-Lamotte (1964) for Timimoun; Taine-Cheikh (2008) for Zenaga.

1.1. A note on phonology. Siwi [e] and [o] occur only word-medially, never word-initially or word-finally. In Arabic loans, they correspond regularly to Classical Arabic word-internal /ay/ and /aw/, typically realized in regional dialects as /e/ $/$ and / $\overline{0} /$. Conversely, the diphthongs conventionally transcribed as [ay $]^{2}$ and [aw] occur word-finally but not word-internally (with rare exceptions in Arabic loans). In this position, they reflect Classical Arabic /ay/ and /aw/ just as /e/ and /o/ do word-internally (e.g. attaw 'light' < Arabic daw'). Synchronically, the obvious conclusion is that [ay] and [aw] are allophones of /e/ and /o/ respectively, and this is supported by some alternations (see 2).

However, their history appears to be different: [ay] and [aw] correspond regularly to vowel+y, $\mathrm{w}$ in languages that have preserved such combinations, rather than to monophthongs: e.g. Siwi əẓmay "sew (palm strips)" = Tamasheq ązməy "sew (clothing, tent)"; Siwi adday "below" = Tamasheq ádday "the lowest"; Siwi iraw "give birth" = Tamasheq arzw "id.", Siwi ayraw "halfripe date' $=$ Sokna $<$ argâu $>^{3}$. Siwi's non-final allomorphs [e], [o], on the other hand, correspond not only to diphthongs (in particular /ăy/) but also to monophthongs $(/ \mathrm{i} /, / \mathrm{u} /)$ in such languages, a phenomenon requiring explanation. This article will therefore focus on the history of non-final /e/ and $/ \mathrm{o} /$.

\section{Mid vowels in Siwi morphology}

In Siwi, /e/ never occurs in verbal morphology proper: not in imperatives, not in perfectives, not in imperfectives, not in infinitives, nor in subject or dative agreement affixes. This contrasts with Tuareg, in which $e$ notably occurs in parts of the conjugation of the perfectives of former glottalfinal verbs (and in the negative perfective, lost in Siwi). As Kossmann (2001) shows, Tuareg and Ghadames have a vowel $e$ in the $1 \mathrm{sg}$. and $2 \mathrm{sg}$. forms of *CC? verbs. Siwi has $-i$ - in these forms:

2 Throughout this paper, in phonetic as well as phonological transcriptions, $<\mathrm{y}>$ will be used in place of IPA [j].

3 Note, however, the less obvious correspondences in Siwi ajraw "frog" = Tamasheq e-jărr "id.", Tahaggart aǵăru "id." (Ritter 2009), Siwi aččaw "horn" = Tamasheq isakk "id." The latter seems to be a back-formation from the plural *askaw-ăn. 
Table 1. $1 \mathrm{sg}$. and $2 \mathrm{sg}$. forms of $* \mathrm{CC}$ ? verbs

$\begin{array}{llll} & \text { Siwi } & \text { Tuareg } & \text { Ghadames } \\ \text { I wore } & \text { alsix } & \text { ălsey } & \text { ălsec } \\ \text { you sg. wore } & \text { alsit } & \text { tălsed } & \text { tălset }\end{array}$

There are two marginal exceptions. The $a$ of the irrealis prefix $g a$ - becomes $e$ when directly followed by the 3rd person subject marker $y$; and the -ay of verbs ending in -ay becomes -e- before a pronominal object suffix, e.g. așșe-t "take it (m.)!" < așsay "take!", and before the imperative plural suffix -wat (cp. Naumann 2012:305, who finds this alternation for non-emphatic contexts only, and analyses the resulting surface [e:] as /ay/). However, the latter ending is reduced to $-y$ before a subject or dative agreement marker, eg așsy-ən / așsi-n "they took". The distribution observed in this context can be explained without reference to specific morphemes: stem-final -ay becomes $>e /[\mathrm{C}$, but $>y /$ V.

Third person pronominal direct objects directly following a verb stem ending in a consonant or featuring an alternating vowel (originally ${ }^{*}$ ) ) are marked by the verbal suffixes $3 \mathrm{MSg}-a, 3 \mathrm{FSg}-e t$, 3P1 -en (Souag 2013:46-47). These correspond in distribution as well as in form to Figuig -i, -it, $i n$, and in form to Tuareg -e, -et, -en, which however appear only after verb stems with alternating vowels (Brugnatelli 1993, Kossmann 1997). Note that 3MSg $-a$ irregularly becomes $-i$ - when the resultative suffix - $a$ is added: $y \partial-z r-a$ (3MSg-see-3MSgDO) "he saw it" > yz-zr-iyy- $a$ (3MSg-see3MSgDO-RES) "he has seen it".

A similar series is used for 2 nd person pronominal direct objects in all circumstances except following $1 \mathrm{Sg}$ subject agreement: $2 \mathrm{MSg}-e k, 2 \mathrm{FSg}-e m, 2 \mathrm{Pl}$-ewan. The corresponding forms in other Berber languages often show analogical reshaping, but insofar as they do correspond, show $/ \mathrm{i} /$ rather than /e/: Tamasheq and Tamajeq use $-i-k,-i-m,-i$-wăn after verbs ending in a vowel (Heath 2005:604, Kossmann 2011:79).

The regular feminine plural ending for nouns is -en, corresponding to -in in most Berber languages, but to Tuareg and Ghadames -en and Ghomara -an:

Table 2. Feminine singular and plural reflexes of "white".

$\begin{array}{llll} & \text { singular } & \text { plural } & \\ \text { Kabyle } & \underline{\text { tamallalt }} & \text { timallalin } & \text { "white (f.); egg" } \\ \text { Tamasheq } & \text { tamallalt } & \text { timallalen } & \text { "white one (f.)" } \\ \text { Ghadames } & \text { tamallilt } & \text { tmallilen } & \text { "dune sand" } \\ \text { Ghomara } & \text { tamallult } & \text { timallulan } & \text { "white person (f.)" } \\ \text { Siwi } & \text { tamallalt } & \text { timallalen } & \text { "white (f.)" }\end{array}$

One noun, ammma "my mother", irregularly becomes ammme- when the possessive suffixes are added: ammme-s "his/her mother". Contrast ammma "my brother", ammma-s "his/her brother". A similar differentiation at the lexical level, though not within the respective paradigms, is found in El-Fogaha and in Nefusi (Paradisi 1963, Beguinot 1942). 
Table 3. Possessed reflexes of "mother", "brother".

\begin{tabular}{|c|c|c|c|c|}
\hline & my mother & his mother & my brother & his brother \\
\hline Siwi & aṃma & sṃmes & ammma & ammmas \\
\hline El-Fogaha & émmi & émmis & ammâi & ammâs \\
\hline Nefusi & émmi & & rûmmu & \\
\hline
\end{tabular}

This differentiation is hard to explain, since "brother" across Berber derives historically from "son of mother ( $m a)$ "; nevertheless, it appears clearly in these varieties.

Medial demonstratives in Siwi agree in number and gender with the addressee as well as, separately, with the referent (see Souag 2014). This demonstrative addressee agreement uses the suffixes $2 \mathrm{MSg}-o k, 2 \mathrm{FSg}-o m, 2 \mathrm{Pl}$-erwan; these derive irregularly from - $a-y u r->-o-$ and $-a-y u r-a-$ $>-e$ - (Souag 2009).

$\mathrm{An} / \mathrm{e} /$ also occurs in the characteristic noun template $\mathrm{a}-\mathrm{C} \partial \mathrm{CCe} \mathrm{C} i$, which applies to Arabic and Berber roots alike: for the latter, eg adiyyezi "singer", ajallewi "person prone to swearing", akakkewi "sniffy", aruwweli "cowardly", asiweli "talkative". Souag (2009) derives this template from Arabic $\mathrm{CaCC} \overline{\mathrm{C}} \mathrm{C} \overline{1}$, so it will not be discussed here.

\section{Lexical items containing mid vowels}

3.1. Vocabulary with /e/. While /e/ is not particularly common in inherited Siwi vocabulary, at least sixteen non-Arabic Siwi words with /e/ have known Berber cognates. In six cases, these correspond to reflexes of $*_{i}$ or $*_{e}$ elsewhere:

*e:

(1) asen "tooth; stone used to block water flow" (Naumann id. "tooth"): Ghomara asan "tooth"; Tamasheq e-sen / e-săyn “id.", Sokna <îsin> “id.”, El-Fogaha <isîn> “id.", Ghadames asén "id.", Nefusi $<\sin >$ "id."

(2) agnen "type of basket"; cp. Ghadames tažnent "wicker basket", Awjila agənnín "a small cushion one wears on the head to carry loads", El-Fogaha $<$ tegnît $>$ "recipient made of palm fibers", Nefusi <ugnîn> "small wicker basket" (Provasi 1973), Tashlhiyt ag"nin "basket made of alfalfa grass", etc. (Kossmann 1999: $\{415\}$ )

$* i$ :

(3) ayel "upper arm": Ghomara ayil (ya-) "mountain/hill", Ghadames ayil "arm", Tamasheq ayil "elbow span”, Sokna < gīl > "arm”, El-Fogaha <agíl, agẹẹll> "id."

Either $*_{i}$ or $*_{e}$ :

(4) ayez "necklace" (Naumann id.): Awjila ayiz 'id.'

(5) atteg "best sort of date, best dates in a bunch" (Naumann atteg "half-ripe date"): cp.

Ouargli utțig "type of date, half ripe date" 
(6) teda "unfertilized dates": Tuareg teda "date without a core" (Prasse 1974:347, Sigwarth n.d.:15), Ghadames tidi "unfertilized date"

In another five cases, they correspond to reflexes of *ăy (although "come!" is somewhat irregular):

(7) hed "come!" (Naumann id.): Sokna <áit> “id.", El-Fogaha <nâid> “id.", Tamasheq iyăw "id.”, Tamajeq (W Y) ăyăw "id.”, Awjila yid "id.”

(8) teni "dates" (Naumann tini "date(s) of Saidi variety"): Tamasheq te-hăyne "id.", Zenaga täynih "id."; Ghadames aßena "date"

(9) tiset "large bowl made from palm leaves, used for rolling couscous" (Naumann id. "table mat"): Tamasheq tesăyt "winnowing van", Tamajeq tesăyt "id."

(10) tiyeda "female goats" (Naumann id.), sg. tyatt: Ouargla tiyəydət/tiyədt pl. tiyəydad/tiyəydad "female goat, goat kid", Tamasheq teyăydătt pl. tiyăydaten "female goat kid"

(11) (Naumann iyed "male goat"): Ghadames a sid "goat kid", Ouargla iyid, izəyd "billy goat, goat kid", Tamasheq e-răyd "male goat kid"

To this list we may tentatively add a masculine pluralis tantum (the masculine plural ending is normally -ən) corresponding to a verb with a root-final $y$ :

(12) išsršen "urine" (Naumann id.) < šərš "urinate" (int. šərša/šəršay): cp. Sokna <išeršīn> "urine", < šérši > "urinate", El-Fogaha <išêršēn, išeršên > "urine", < <̌érši > "urinate". This root is attested as such only in Siwa, Sokna, and El-Fogaha, according to Nait-Zerrad (1999:243).

In two cases, Siwi $e$ corresponds in other languages to reflexes of * $\breve{a}$. In both, the vowel is adjacent to $\check{c} / j^{4}$.

(13) aččer "fingernail” (Naumann: id.): Sokna <iššěr> "id."; Ouargla a ̌̌̌šar "id."; Ghadames aškar (Ghadames uses the plural stem in the sg.) "id.”; Tamasheq eskăr, Tamajeq eškăr “id.", Zng. askär "id." ajmej "slave” (Naumann id.): Figuig išməž “id.", Ouargla isməž “id.”

For fuller discussion of this correspondence, see section 5.4.

None of the remaining words with /e/ are useful. Of the three with plausible Berber etymologies, one's relevant vowel remains unknown:

(15) azureg "adolescent (15-18 years old)": Tamajeq zurag "to be completely free, be independent"

The other two seem to have had their vowel pattern reformed to fit an Arabic diminutive template (CCēC):

4 Note that Siwi /j/ is variously realized as [̌̌] or [dž], two allomorphs of the same phoneme often found in free variation (cp. Naumann 2012:152). 
(16) afred "stone mortar (for crushing date seeds, salt)" (Naumann affred "small mortar"): cp. Figuig afordu "mortar", Nait-Zerrad (2002, s.v. FRD 2).

(17) agbez “cowrie”; cp. Tamasheq ašbəğ 'man's bracelet', Middle Atlas azbəy 'id.' (with metathesis)

Four are probably dialectal Arabic loanwords, despite being unattested as such in Arabic dictionaries:

(18) ambej "pocket" (Naumann id.): cp. Arabic jayb, southern Arabic article am- (Souag 2013:79, Laoust 1932:280)

(19) anneb "large piece of meat" (Naumann id. "piece of meat"): cp. Arabic nayyaba "sink one's (canine) teeth into (an animal)", nāb "canine tooth"

(20) aqarqweč “cartilage" (Naumann id. "upper rim of ear"): cp. Egyptian Arabic qarqaš "crunch" (Hinds \& Badawi 1986:696)

(21) abargen "round hole with manure inside" (Naumann id. "hole dug in the ground to put in a young plant"); cp. Kabyle abruğ "hole", derived by Dallet (1982) from Arabic

One more is certainly an early loan, cognate with English "Saracen" (Vycichl 2005:192), from Greek or Coptic sarakênos:

(22) asarłen "Bedouin" (Naumann: aṣaryen, Vycichl: aṣeṛên): cp. Awjila ašəryín "id."

The remaining five have no clear Berber or Arabic cognates, although some tentative comparisons may be suggested:

(23) agzen "bird species; term of endearment used to children"; ?cp. Ghadames agzen "pup"

(24) agazwer "little piece of wood" (Naumann agazwar "splinter"); ?cp. Ghadames ăgzər "cut bunches of dates"

(25) ayarḅej "dates that have dried up before ripening", ?cp. Kabyle agarbuž "an object of little value, junk" (Omar Mouffok, p.c.)

(26) ițrgen "diarrhea excrement" (probably with a root-final $y$, cp. išsršen "urine" above)

(27) akules "dark soil (loam?)"

A special case, much better attested with /i/ but apparently showing variation (perhaps to be explained by question prosody, which in Siwi often affects the last syllable's vowel), is:

(28) amnit/amnet "how much, how many" (Naumann: mnit): Tamasheq man-íket "id.", Ouargla mənnəšt "id.", Zraoua mənyət "id." (Souag, field notes), Sokna $<$ menīt $>$ "id."

In the case of (8) teni 'date', Souag and Naumann disagree on whether the vowel in question is /i/ or /e/; this may reflect dialectal/idiolectal variation.

5 Transcribed in Souag (2013) as asaryin, but now re-checked against audio; the $\gamma$ makes it difficult to distinguish $i$ from $e$, but the vowel is clearly lowered. 
3.2. Vocabulary with /o/. Excluding Arabic borrowings as before, the vowel /o/ is much rarer in Siwi even than /e/. The only unambiguous examples of /o/ in Berber vocabulary occur in two words, both of the shape aCCoC:

(29) allon "window" (Naumann id.): Ghadames allun "hole", Ouargli allun "bird coop, dog house, niche"

(30) agroz "palm heart”: El-Fogaha <agrûz> “id.”, Ouargli agruz “id.”, Gh. aǵaruz “id.”, Sokna agruz "id."

In the latter, it is unclear whether the final consonant was originally emphatic, which could have influenced the $/ \mathrm{o} /$.

Two other cases have no known cognates, and may be loans:

(31) ttorabt "trunk, olive log" (Naumann: tturaḅt "tree trunk")

(32) koča "type of olive"

Naumann adds the obviously onomatopoeic:

qoqoq "goose"

In one case, Souag and Naumann disagree on whether the vowel in question is $/ \mathrm{u} / \mathrm{or} / \mathrm{o} /$; this undoubtedly reflects the difficulty of distinguishing the two in an emphatic context.

\section{Regular reflexes of Berber $e$ in Siwa}

Siwi /e/ sometimes corresponds to $e$ in Tuareg and Ghadames. At first sight, these look like retentions of original $* e$, but this is problematic, since Siwi more often has $/ \mathrm{i} /$ for ${ }^{*} \mathrm{e}$.

4.1. Reflexes of $* \boldsymbol{e}$ in the nominal prefix. The prefix $e$-/te- of Tuareg, corresponding to the weak $i$-/ti- in Moroccan-Algerian Berber, is regularly $i$-/ti- in Siwi (Van Putten forthcoming):

(34) ifoff "breast", cp. Tamasheq e-fäff "id."

(35) iyed "billy goat", cp. Tamasheq e-yăyd "id."

(36) illi "millet", cp. Tamasheq e-năle "id."

(37) ilam "skin (thin)", cp. Tamasheq e-lăm "(human or living animal) skin"

(38) inir "lamp", Tahaggart e-ner "oil lamp" (Ritter 2009), Ghadames énér "id."

(39) tizagnat “needle', cp. Kabyle ti-ssagnit 'id.'

6 While Lanfry transcribes this with a non-emphatic z, the Facebook page Awal n $\varepsilon$ deməs, apparently by a native speaker, specifically states that this word has an emphatic z, after transcribing it as <'jrwz> (https://www.facebook.com/134561076656556/photos/a.134596359986361.25645.134561076656556/36 6869620092366/?type=1, viewed 16 December 2014).

7 No. 96 in Scid n Yunes' 2010 vocabulary of Sokna Berber (http://www.tawalt.com/?p=5390, viewed 16 December 2014.) 
(40) izəm "gazelle, ibex”, cp. Tahaggart $e$-hăm “id.", Tamasheq $e$-šăm “id.”, Tamajeq e-zăm "oryx", Zenaga äžzmmi "Gazella rufifrons (Hassaniya dāmi)"

(41) tizmərt "ewe", cp. Kabyle i-zimər "lamb", Figuig izmər "id.", Tamasheq e-zemər "id."

(42) ikarkar / alkarkar "chest", cp. Tamasheq e-ğărğăr "upper torso (front and back, down to ribs)"; Zenaga ägärgur "chest""

In front of original CC, $i$ regularly shortens to $\partial:^{9}$

(43) təmsi "fire", cp. Tuareg te-mse, t-emse, tă-mse "hell, hellfire", Figuig ti-msi "fever"

In a few cases the prefix $e$-/te- has been replaced by the more common $a$-/ta-:

(44) talšat "louse", cp. Sokna <tiršít> "id.", Kabyle ti-lkit "id."

(45) tamdi "large ant", cp. Tamasheq te-medhe "termite", Timimoun ti-mdi "id."

(46) asen "tooth", cp. Tamasheq $e$-sen "id."

(47) axfi "head", cp. Tamasheq $e$-yăf "id."

The first three look like good candidates for back-formation from the plural, on semantic grounds; the last also shows an irregular correspondence in the final vowel.

4.2. Reflexes of $* \boldsymbol{e}$ word-internally. We also find Siwa $i$ word-internally in several places where it corresponds to $* e$, as well as the $1 \mathrm{sg}$ and $2 \mathrm{sg}$ reflexes of CC? verbs -ix, -it, as discussed above:

(48) abdir "pigeon", cp. Tamasheq e-dăber "id."; Ghadames adaber /adăber/? "id."

(49) aglim "skin", cp. Tamasheq ağlem "prayer skin"

(50) inir "lamp", cp. Ghadames ener "id.", Tahaggart e-ner "oil lamp" (Ritter 2009)

(51) izit "donkey”, cp. Tamasheq e-šed "id.", Ghadames azéd "id.”"10

Like other/i/s (and /e/s), it is regularly shortened to /a/ before two consonants:

tabdort "female pigeon"

Another example of the $i$ reflex of *e might be found in the word for 'navel'. The $i$ has been regularly shortened in the singular in front of $\mathrm{CC}$, but shows up again in the plural. However, the root-final consonant's fluctuation across languages proves that analogy has been at work, which makes it difficult to take the vowel $i$ as necessarily etymological here.

8 The correspondence Siwa $k$ - Tamasheq $\check{g}$ is irregular.

9 When a vowel formerly used to separate the two consonants, the prefix is not shortened, e.g. illi 'millet' (cp. Tuareg e-năle), ijdi 'dust' (cp. Tuareg e-ǵede 'dune').

10 The initial $i$ - which appears to correspond to $e$ - probably cannot be seen as evidence of $i$ - corresponding to $e$ - word initially. The $e$ - found in Tuareg is likely the result of the sequence $a-y, \mathrm{cp}$. Ahaggar eyhed "donkey". Initial ay regularly becomes ey in Ahagger and $e$ in Tamasheq, cp. Kabyle aydi "dog", Ahaggar eydi "id." Tamasheq edi "id.". Initial ay regularly yields $i$ in Siwi (see section 5.1). For further discussion, see Kossmann (1999: 229-32) 
(53) timatt pl. timiten "navel”, cp. Ghadames tamet pl. tmedén "id.", Tamasheq te-mett "umbilical cord" pl. ti-meden "placenta"

In nearly as many words, however, as well as in the 3Fsg and 3P1 pronominal direct object suffixes -et, -en and the FPl nominal suffix -en, *e corresponds to /e/ rather than to /i/, as seen above:

(54) asen "tooth; stone used to block water flow" (Naumann id. "tooth"): Ghomara asan "tooth"; Tamasheq e-sen / e-săyn "id.", Ghadames asen "id."

(55) agnen "type of basket"; cp. Ghadames tažnent 'wicker basket' etc. (Kossmann 1999: $\{415\})$

(56) teda "unfertilized dates": Tahaggart teda "date without a core" (Prasse 1974:347), but Ghadames tidi "unfertilized date"

In $\mathrm{CeC}(\mathrm{C}) \mathrm{e}$ stems, it corresponds to zero, due to a sound shift also affecting other Zenati languages (see Kossmann 1999: 140, footnote 7):

(57) amdi "large ant", cp. Tamasheq te-medhe "termite", Timimoun ti-mdi "id."

(58) ijdi "dust", cp. Tamahaq e-ǵede "dune", Ouargla iždi "sand" (this word shows i/e variation in Tuareg: contrast Tamajeq Y agedi, W agidi. cp. Ritter (2009:161.) In view of the rarity of final $-e$ in nouns, the forms with $-i$ are probably secondary.)

A similar shift in stems of the form eCe is discussed in the next section.

4.3. Reflexes of * $\boldsymbol{e}$ word-finally. Final $-e$ regularly becomes $-i$, as illustrated by the following cases (and by the verbal noun formation discussed below, if the comparison to Tuareg is accepted):

(59) illi "millet", cp. Tamasheq e-năle "id."

(60) ijdi "dust", cp. Tamahaq e-ǵede "dune" (this word shows i/e variation in Tuareg, as seen in 4.2.)

(61) təmsi "fire", cp. Tamasheq te-mse, t-emse, tă-mse "hell, hellfire", Figuig ti-msi "fever"

(62) tifri "ringworm (skin disease)", cp. Tamasheq tă-fore 'small skin sore on head or body'

(63) takəčči "worm”, cp. Tamasheq ta-wəkke "earthworm", Sokna <tagěččî> "id."

(64) tamdi "large ant", cp. Tamasheq te-medhe "termite", Timimoun ti-mdi "id."

(65) tṃəryi "locust", cp. Ghadames tomařse "id."

(66) teni "dates", cp. Tamasheq te-hăyne "id."

However, words of the form $t-e C e$ (cp. Prasse 1974:346) become $t$-Ca:

(67) tla 'shadow', cp. Tamasheq t-ele 'shade'

(68) tza 'udder', cp. Tamasheq t-eze 'udder'

The same correspondence between Tuareg $e$ and Siwi $a$ is observed in the $3 \mathrm{SgM}$ pronominal direct object suffix $-a$ (as seen above), whose history is harder to reconstruct. 
Internal $-e$ before the feminine ending $-t(<-t t$ ? $)$ is shortened to $\partial$, as is $i$ in the same context: (69) tisat 'mirror' cp. Tamasheq t-isett 'id.'

Early 19 th century sources suggest that this merger of $*_{-} e$ with $*_{-} i$ may be relatively recent; the former is often transcribed as [a], while the latter consistently appears as [i]. Consider:

Table 3: Early transcriptions of reflexes of $*_{-} e$ and $*_{-i} i$ in Siwi.

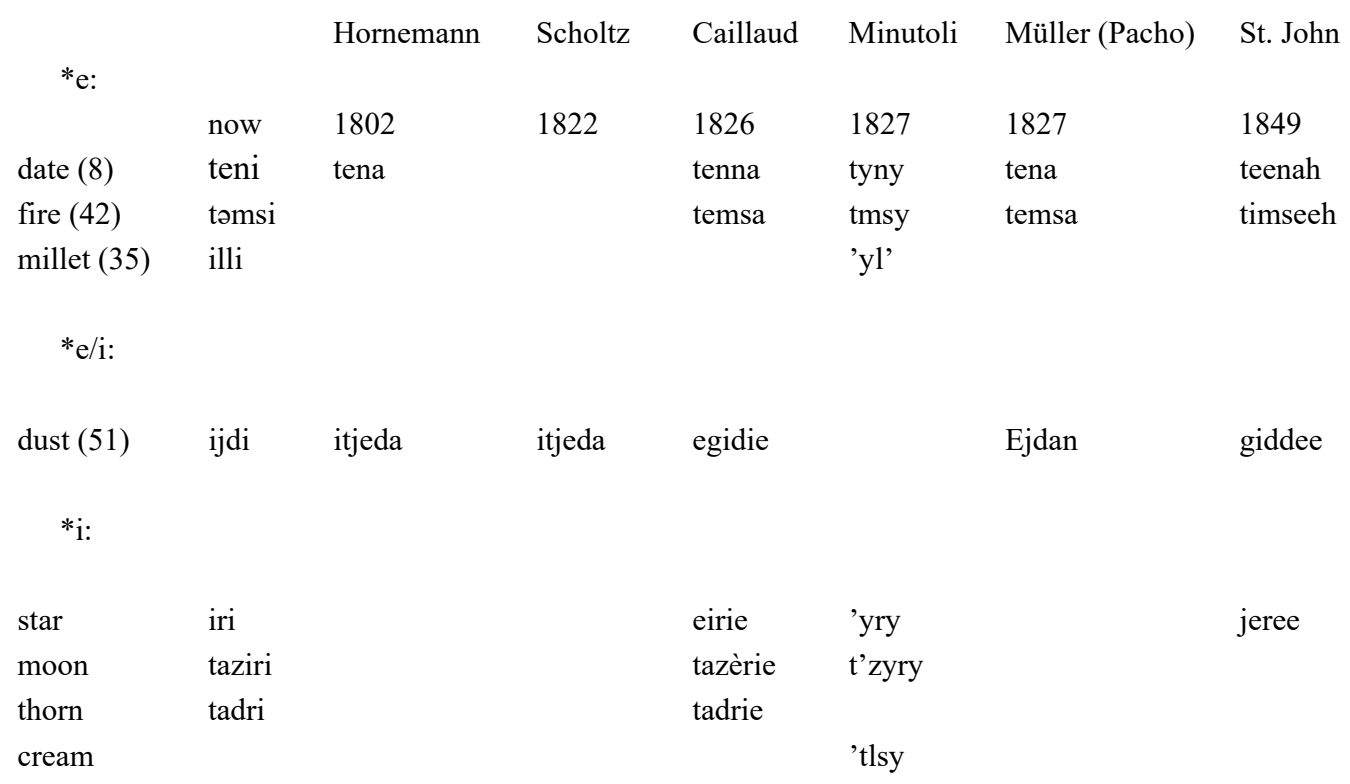

Later sources consistently transcribe both sets with [i], and Minutoli's informant transcribes both with $<y>$ (with the sole exception of "millet"). It is easier to imagine that "date", at least, was still pronounced with a lower vowel ([tenc]?) than to suppose that French, German, and English speakers all independently misheard [teni] as [tena].

4.4. Reflexes of * $\boldsymbol{e}$ in verbal nouns. In Siwi, $t i-\ldots-i$ is the regular VN formation for CCV stems with the imperfective $t \partial C C a C$, which are the regular outcome of ${ }^{*} \mathrm{CC}$ stems, and for $\mathrm{VCC}, \mathrm{VCV}$ and CVC stems.

(70) tifli VN of $f \partial l$ impf. təffal "go away"

(71) tigli VN of ugal "hang"

(72) tifi VN of if "find"

(73) tifiti VN of fat "yawn"

It is not the regular $\mathrm{VN}$ formation of $\mathrm{CCV}$ stems with the imperfective $C \partial C C$, which are the regular outcome of $* \mathrm{CC}$ ? stems. 
(74) aпәууа VN of nәу impf. nәуу "kill"

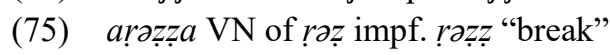

It is tempting to compare this to the te-CăCe/te-CăCCe verbal noun formation in Tuareg (and elsewhere), but this is distributionally problematic. This formation is primarily found for *CC? stems, which is exactly where it does not occur in Siwi, e.g.

(76) Tamasheq te-năye VN of ăny "to kill"

(77) Tamasheq te-răgzze VN of ărz "to break"

However, it sometimes occurs with other root types; e.g. abdad 'to stand, stop' has the verbal noun te-hădde. ${ }^{11}$

The Siwi formation looks like the general Berber formation, but it is unclear why Siwi uses it specifically for non-*CC? stems while other Berber languages use it almost exclusively for ${ }^{*} \mathrm{CC}$ ? stems.

\section{The origins of Siwi /e/}

We have now seen that, notwithstanding the examples in 3.1, etymological $* e$ is commonly reflected as $i$ in Siwi in initial, medial, and final position. Conversely, etymological $*_{i}$ is reflected as $e$ in Siwi in ayel "arm" (\#3) and (arguably) in the 2nd person pronominal direct object suffixes $e k$, $-e m$, -ewan. This puts into question whether there is ever any direct historical connection between Siwi $e$ and etymological $*$. To address this, it is necessary to view the external correspondences of Siwi /e/ all together.

5.1. Correspondence of /e/ to * $\breve{a} \boldsymbol{y}$. Word-internally, Siwi does not normally allow diphthongs. It thus seems reasonable to assume that /e/ is in fact the regular reflex of word-internal *ay $y$ in Siwi, as in the five examples given in 3.1 and probably also in išoršen (\#12) and iţrgen (\#26). Wordfinally, we have seen that this diphthong becomes [ay]; there are no clear examples of it wordinitially, but initial *ay- seems to become $i$-:

(78) itma "my brothers", cp. Middle Atlas aytma "id."; Tashlhiyt aytma "id."; Kabyle atma "id."; Petit Kabyle aytma "id."; Tamasheq ayətma "id."; Figuig ayətma "id."; Nefusi <āītmâ> "id." (Kossmann 1999: \{606\})

(79) inir "forehead", cp. Ghadames enar "id."; Kabyle anyir "id."; Medieval Tashlhiyt aynər “id.”, Figuig tanyərt “id.”, Middle Atlas ayənyir, ayənri (Izd). (<*taynərt ?? Kossmann 1999: $\{604\})$

However, the shift $*-\breve{a} y$ - $>-e$ - leaves the majority of instances of /e/ unaccounted for.

5.2. Correspondence of /e/ to * $\boldsymbol{e}$ before $/ \mathbf{n} /$. We have now seen that Siwi $e$ unambiguously corresponds to original *e only in two nouns, asen "tooth" (\#1) and agnen "type of basket" (\#2), as well as in the feminine plural -en and the 3rd person pronominal direct object suffixes 3FSg -et

11 Cognates are widespread, e.g. Middle Atlas badd "to stand", $t$-iddi "height"; Figuig badd "to stand", $t$ iddi "height". 
and 3Pl -en. (We exclude amnit/smnet 'how much, how many', since the better attested variant has $i$; its correspondences are also problematic, due to the irregular loss of $k$ ). Of these, asen, agnen, FPl -en, and 3Pl -en all end in the nasal $n$ - as do the more etymologically problematic forms asaryen (\#22), abargen (\#21), agzen (\#23), and itargen (\#26). This might suggest that in Siwi $n$ originally conditioned a lowering of preceding $i$. However, three inherited demonstrative morphemes feature final -in, making a conditioning explanation unlikely:

-in:

(80) widin "those" (pl. distal demonstrative); cp. Kabyle wid "those who", wihi $\underline{d}$ "those"

(81) wihin "whatchamacallit" (wih "that (m. sg. distal demonstrative)")

(82) bottin "who?” (batta 'what?')

-din:

(83) sradin "this morning" (sra "morning")

(84) luqaddin "back then, a little while ago" (Ar. al-waqt "time")

(85) nhardin "in the old days, back then" (Ar. nahär "day")

(86) annijdin (proper name of a place in Siwa) < annij "above"?

(87) slațtin "yesterday" < *sal-iț-din "other.than-night-deictic". Cp. Tamasheq săl "other than..., except...", (ášəl wen) săl ašəkka "day after tomorrow”; Kable sall-iḍlli "day before yesterday", səll-azəkka "day after tomorrow"

-əllin:

(88) iṭallin "last night” (iṭa "tonight ); cp. Sokna < ḍāllín> "yesterday”, El-Fogaha <aḍallîn> “id.” vs. Kabyle id̨lli “id.” (iḍ "night”); Tashlhiyt -lli (anaphoric deictic suffix)

This makes an alternative hypothesis preferable: that an original /e/-/i/ distinction was preserved only before $n$ (in this case, -et would have been restored by analogy with -en). Final *e was probably preserved well into the 19th century, and Siwi vowel-final words are often pronounced with an epenthetic final [y] (cp. Naumann 2012:291), so the environments _\# and_n\# are even more similar than they appear.

5.3. Correspondence of /e/ to *i after $\boldsymbol{y}$. The cases of ayel (\#3), ayez (\#4), and asaryen (\#22) might suggest that $y$ lowers an immediately following $i$ to $e$. A search of the Siwi lexicon reveals that $y i$ occurs word-internally in inherited vocabulary only before $y y$ - a context in which the $i$ is to be analyzed as underlying $ə$ - so this explanation appears plausible. Even in Arabic loans, it is limited to aryif "bread" (which Naumann transcribes with an $e$ ) and yiwal "hurry", so it may be tenable as a synchronic phonological rule rather than just a diachronic one. Despite their irregular history, /e/ and /o/ in demonstrative addressee agreement suffixes also reflect the historic presence of a preceding $/ \mathrm{\gamma} /$.

5.4. Correspondence of /e/ to $* \breve{a}$ next to post-alveolars. As seen in section 3.1 there are two Siwi nouns which have $e$ in the position of a short vowel in other Berber varieties, namely: aččer 
"finger nail" (\#13) and ajmej "slave" (\#14). This sound shift is not found in other words of the shape aCCəC: contrast adyən "rug", afqad "eggs cooked with flour and oil", agbən "house", agzab "lower part of palm frond", ayrəm "large seed", akbər "robe", etc.

In both words, the $e$ is adjacent to a post-alveolar consonant (cp. Souag 2013:23). In fact, $\partial$ is attested next to post-alveolars only in verbs - eg anjaf "marry", raj "dream", čaxčax "sprinkle water" - and in nouns with the countable feminine suffix -ət (from *-itt), eg tamıčč tarjat "ember". In other contexts, the only occurrences of $ə$ next to a post-alveolar are $u s ̌ z k$ "date sp." and the presumably onomatopoeic form čarčər "duck", neither of which have any known Berber cognates. In verbs, the $a$ may have been restored analogically (more recent changes, such as $-\partial \gamma>-a \gamma$, are less consistently applied to verbs than to nouns, presumably for that reason). So the absence of a next to $\{\check{c}\lceil j\}$ in final syllables apart from such cases makes it plausible to postulate a sound change $\mathrm{C} ə \mathrm{CH}>\mathrm{CeC} /\{\check{c} \mid \mathrm{j}\}$ in final syllables.

As it stands, however, such a rule would predict that proto-Berber *amǵar "sickle" (\#78) should have become unattested *amjer in Siwi, rather than attested amjir ( $*$ g being the only regular source of Siwi $j$ ). It is not possible to postulate a shift $i>e$ conditioned by post-alveolars; $i$ regularly occurs next to post-alveolars, eg amjir "sickle", jij "peg in wall”, annij "above". Rather, the problem can be resolved by supposing that the change predates the merger of proto-Berber * $\breve{a}$ with *ə in Siwi: ${ }^{*} \mathrm{C} ə \mathrm{C} \#>\mathrm{CiCH} /\{\check{\mathrm{c}} \mid \mathrm{j}\}$, but $* \mathrm{Ca} \mathrm{C} \#>\mathrm{CeC} \# /\{\check{c} \mid \mathrm{j}\} .{ }^{12}$ Thus:

with *ə:

(89) nnij “above”, cp. Ghadames innəž, yənnəž “id.”, Tamasheq dənnəg “id.”, El-Fogaha $<$ ínniž> "id."

(90) amjir "sickle”, cp. Middle Atlas $a-m g^{w} ə r$ "id.", Kabyle $a$-mgər "id.”, Figuig $a$-mžər "id.", Tashlhiyt $i$-mgr "id." 13

with $* \breve{a}$ :

(91) aččer "fingernail” (Naumann: id.): Sokna <iššêr> “id.", Kabyle ǐ̌šsr "id.", Tuareg eskăar "id.”, Ouargla ǎšsar "id.”, Zenaga askär "id.”, Ghadames aškar "id." 14 ajmej "slave" (Naumann id.): Figuig išməš “id.”, Ouargla isməž “id."

5.5. Remaining anomalies. None of the proposed shifts can explain the following items known to be of Berber origin: the pronominal 3FSgDO -et, and the 2nd person direct object pronominal

12 For another potential example, niš "I", it is unclear whether to reconstruct * $\breve{a}$ or *ə; Tuareg has năkk but Zenaga has $n i$ ? K. The Siwi reflex fits the latter, but irregularly lacks final gemination, and is frequently pronounced nəš phrase-internally.

13 This word has no cognates in languages retaining the short vowel contrast. However, the fact that the form is aCCəC in all languages but Tashelhiyt (Kossmann 1999: \{317\}) suggests that the vocalism contained ə-vowels in the stem (Van Putten forthcoming).

14 The Ouargla and Ghadames forms are backformations of the plural stem *askar (Kossmann 1999: $\{515\})$.

15 This word is reconstructed as *e-sămăg gased on the presence of the prefix $i$ - in all its cognates but Siwi and Timimoun (Kossmann 1999: $\{626\}$ ). The prefix $i$ - is conditioned by the presence of the vowel $\breve{a}$. Other i-CCəC nouns, such as Figuig $i$-yzar 'valley' can be shown to come from *e-CăCăC (Van Putten forthcoming). 
suffixes; the unexpected /e/ in ammene-s "his mother" (Table 3); and the words teda (6), atteg (5), azureg (15). The pronominal direct object suffixes can be adequately explained by analogy; the unetymological /e/ in the 2nd person forms must reflect paradigmatic levelling based on 3PIDO en, making the same explanation more plausible for $3 \mathrm{FSgDO}$. For ammene-s, only two clear cognates are known, making reconstruction difficult.

Of the remaining three words, teda (\#6) may feature irregular retention of word-internal $e$, judging by the Tuareg cognate teda; however, the Ghadames cognate tidi, corresponding irregularly to both the others, complicates the etymology. The original vocalism of azureg (\#15) is unreconstructible, and, like atteg (\#15), it has only one known cognate. It thus seems advisable to leave all three as mysteries for further work to resolve. However, two of these problems could be avoided by noting that Siwi has no known words ending in -ig (and no inherited ones ending in $i k$ ); nothing, therefore, prevents us from postulating a shift $*_{i}>e / g \#$ (or /_[+velar]), although no direct evidence confirms this either. The latter would even provide an alternative explanation for $2 \mathrm{MSgDO}-e k$.

Among the words of unknown but potentially Berber origin, retention before final $n$ could potentially explain agzen (\#23) and itargen (\#26), as well as abargen (\#21), while the affricate shift could explain ayarbej (\#25). That leaves two problematic words:

(94) akules "dark soil (loam?)"

The hypothesis above cannot be extended to account for either of these; talis 'reservoir' ends in $-i s$, and many words (including several cited above) end in -ir. However, nothing stops us from postulating that these are loans from an unknown source, and doing so is certainly preferable to postulating an extra sound change on such slim evidence.

The existence of these exceptions (at least 3 words, dropping to 1 if we postulate the velar shift; up to 5 if both the problematic etymologies turn out to be Berber) is obviously unsatisfactory. Nevertheless, these are relatively minor in comparison to what we can account for: 16 words - or 18 with the velar shift - and, accepting the analogical explanation, all the morphemes except ammm-es (Table 3).

\section{The origins of Siwi /o/}

6.1. The irrelevance of $/ \mathbf{n} /$. Given the frequency of $e / \ldots$, it might seem tempting to explain the /o/ in allon "window" (\#29) as caused by the following $n$. However, /un/ not only emerges regularly via affixation in the $3 \mathrm{pl}$ of $u$-final verbs, eg yəbdun "they began", but is also attested in at least three non-Arabic words, with no deictic connection:

(95) akərčun "donkey foal": Nefusi <akeršûn> "id."

(96) armun "pomegranate"; Nefusi <armûn> "id."

(97) așəkkun "bunch of grapes"

We must therefore discard the hypothesis that $* u>o /[n$.

If the $e / i$ distinction was preserved before $n$, we might likewise be tempted to extend the same explanation to this case. However, there seems to be no independent evidence for reconstructing 
$*_{o}$ for proto-Berber, in the word "window" or anywhere else - note that the Ghadames and Tuareg cognates of this word use $u$, while Siwi's closest relatives do not have a $u / o$ distinction at all. It is extremely unlikely that an original $u / o$ distinction could have been lost everywhere else in Berber except in Siwi before $/ \mathrm{n} /$.

6.2. The impossibility of identifying a regular source for $/ 0 /$. The two clearcut examples of inherited /o/ - allon (\#29), agroz (\#30) - have in common the presence of a liquid before the o in a final syllable, and a coronal after it. But so do other words, such as:

(98) akarrus "knot"

(99) drus "few"

(100) azamlul "fiber from which rope is made"

The immediate context is thus not adequate to explain the shift. Nor is it the case that all words of the shape $* \mathrm{aCCuC}$ become aCCoC: to the contrary, counterexamples are more frequent than examples, e.g.,

(101) aksum "meat", cp. Kabyle akssum "id."

(102) aṣrum "intestine"; cp. Middle Atlas aṣarm "id."

(103) anšuš "buttock"; cp. Kabyle aməššaš "fesses"

(104) armun "pomegranate"; cp. Nefusi <armûn> "melagrano"

Pending further data, the most that can be said is that words of the shape aCCuC show a sporadic tendency to become aCCoC, perhaps especially in lowering contexts such as before a nasal or an emphatic. ${ }^{16}$

\section{Dating the changes}

Documentation of Siwi begins from the early 19th century. Despite many shortcomings, this early material is sufficient to prove that the emergence of /e/ and /o/ in Siwi predates this period; however, it leaves open the possibility that their spread to some specific words may be more recent.

Three relatively extensive sources describe the Siwi of the early twentieth century. Stanley (1912) clearly distinguishes what he heard as [i] $(<\mathrm{ee}>,<\mathrm{y}>,<\mathrm{i}>)$ from $[\mathrm{e}](<\mathrm{ei}>)$. In final nonemphatic closed syllables, Walker's (1921) eccentric transcription too seems to distinguish [i] $(<\hat{\mathrm{e}} \mathrm{e}(\mathrm{a})>,<\mathrm{i}>,<\hat{\mathrm{l}}>)$ from $[\mathrm{e}](<\mathrm{e}>,<\mathrm{e}>)$. In Laoust (1936), the transcription is rather close to usual academic standards, but the author, likely influenced by his experience of Moroccan Berber, shows a very strong tendency to transcribe $[\mathrm{e}]$ as $/ \mathrm{i} /$, betrayed not only by external comparison but by text-internal variation with $<$ ai $>$. All three authors thus reveal the presence of /e/ - but all three also often write [i] where we expect/e/.

16 We thank an anonymous reviewer for suggesting the latter part of this sentence. 
Table 4. Words with /e/ reflected in at least one source.

$\begin{array}{lllll} & & \text { Stanley } & \text { Walker } & \text { Laoust } \\ & \text { modern } & 1912 & 1921 & 1936 \\ \text { tooth (\#1) } & \text { asen } & \text { asein } & \text { âsen pl. eesenûn } & \text { asẹn, as in } \\ \text { f. pl. } & \text {-en } & \text {-ein } & \text {-èn } & \text {-in } \\ \text { come (\#7) } & \text { hed } & \text { hait } & \text { hairrd } & \text { haid- } \\ \text { 3F/PIDO } & \text {-en/-et } & \text {-ein/-it } & & \text {-(a)in/-(a)it } \\ \text { 2M/FSgDO } & \text {-ek/-em } & \text {-uk } & \text {-ik/-am } & \text {-(a)ik/-(a)im } \\ \text { his mother (Table 3) } & \text { eṃm-es } & & & \text { umma-is } \\ \text { necklace (\#4) } & \text { ayez } & & \text { ághess pl. yeeghésun } \\ \text { urine (\#12) } & \text { išrřsen } & \text { shirshein } & & \text { ayîz } \\ \text { winnowing van (\#9) } & \text { tiset } & & & \text { išəršin } \\ & & & & \text { tisait }\end{array}$

Table 5. Words with /e/ consistently transcribed as a vowel other than [e] in multiple sources.

$\begin{array}{lllll} & & \text { Stanley } & \text { Walker } & \text { Laoust } \\ \text { date }(\# 8) & \text { modern } & 1912 & 1921 & 1936 \\ \text { fingernail }(\# 13) & \text { teni } & & \text { teeanêê } & \text { tiyni } \\ \text { goat }(\# 11) & \text { aččer } & & \text { echêêr pl. echeerrûn } & \text { ačir } \\ \text { pocket }(\# 18) & \text { iłed } & \text { yrid } & & \text { iłid } \\ \text { male slave }(\# 14) & \text { ambej } & \text { ambydj } & & \text { anbiž } \\ \text { 2PIDO } & \text { ajmej } & \text { ydjimidj } & \text { ajmêêj } & \text { ažməž[sic!] } \\ & \text {-ewən } & \text {-oowin } & \text {-ówin } & \text {-îwən }\end{array}$

Minutoli (1827) and Bricchetti-Robetti (1889), written in Arabic characters by native speakers, both transcribe "slave" as <'jmyj $>$, confirming that Laoust's transcription with $ə$ is a Moroccanism.

Caillaud (1826) consistently transcribes words with /e/ as French $[\varepsilon] /[\mathrm{e}]$, never $[\mathrm{i}]$

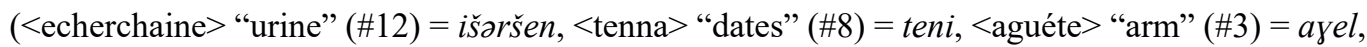
egaite "goat" $(\# 11)=i_{\gamma} e d$, <-enne $>$ "f.pl." = -en); the only exception is <tcharenne > "fingernails" (\#13, ̌̌čerən). ${ }^{17}$ However, the value of this evidence for establishing that /e/ is old is weakened by the fact that, whereas Laoust errs on the side of [i], Caillaud errs on the side of $[\varepsilon] /[\mathrm{e}](<$ témite $>$ "navel" = timatt, $<$ tégourgan $>$ "firewood" = tigurga,$<$ tazèrie $>$ "moon" = taziri $)$. Other early sources are too short to be of much use.

Based on all of this data, we can be confident that /e/ was present in Siwi by the early 20th century, and most probably by the early 19th century, in most of the contexts where it is heard today. While a few words are consistently transcribed by early 20th century sources as having [i], the transcriptions of Caillaud, despite their ambiguity, suggest the presence of [e] in those too (e.g. for iyed, teni).

$17<$ tcharenne> may be an archaism. In other Berber varieties, the plural has a vowel $a$ before the last stem consonant, eg Tamasheq eskăr pl. askarăn. 
For $/ 0 /$, the data to be examined is naturally smaller:

Table 6. Early transcriptions of words containing /o/ in modern Siwi.

$\begin{array}{lllllll} & & \text { Minutoli } & \text { Caillaud } & \text { Stanley } & \text { Walker } & \text { Laoust } \\ & \text { modern } & 1827 & 1826 & 1912 & 1921 & 1936 \\ \text { MSgAddr } & \text {-ok } & \text { (wiyy)awk } & & \text {-oak } & \text {-ûk } & \text {-uk/-ok } \\ \text { FSgAddr } & \text {-om } & & & & \text {-òm } & \text {-om } \\ \text { window (\#30) } & \text { allon } & & \text { aloune } & \text { alone pl. } & \text { allôôun pl. } & \text { allun pl. } \\ & & & & \text { alonin } & \text { alloounîn } & \text { əllûnən } \\ \text { much } & \text { kom } & & \text { côme } & \text { kōm } & \text { kóm } & \text { kûm, kôm }\end{array}$

Minutoli clearly confirms that /o/ was present in Siwi demonstratives by the early 19th century. However, its spread to "window" may be later; Caillaud's distinction between $<$ aloune $>$ and the Arabic loanword $<$ côme $>$ is suggestive.

\section{Conclusion}

In Siwi, proto-Berber *e has shown an overwhelming tendency to disappear from the phonological system by merging with other vowels: in almost all contexts, it has regularly become /i/, while words of the shape *t-eCe have become t-Ca. This tendency, however, has proceeded unevenly, with $* e$ surviving longest in final syllables. Word-finally the reflexes of $* e$ and $* i$ may have remained distinct as late as the late 19th century, and before word-final $n$ the distinction seems to have been maintained up to the present. Outside of the latter context, and excluding loanwords, modern Siwi /e/ derives from three sound changes, completed almost certainly by 1900 and probably before 1820 :

- word-internal monophthongization of the diphthong *ăy

- $\quad * \breve{a}$ in final CVC syllables adjacent to a post-alveolar (a change apparently shared with ElFogaha)

- lowering of $/ \mathrm{i} /$ after $/ \mathrm{\gamma} /$

Another possible context for lowering, before final velars, is not supported by sufficient examples.

The Siwi vowel /o/ derives from Proto-Berber * $u$, irregularly in the demonstratives and sporadically in words of the shape aCCuC. The extreme rarity of the latter change (only two certain examples are attested within inherited vocabulary) makes it impossible to determine its causes more precisely, and it may well postdate the 19th century.

Modern Siwi mid vowels are thus mostly secondary developments; except for final -en, they provide no direct evidence for the reconstruction of mid vowels in earlier intermediate stages of Berber. In this respect, Siwi is more reminiscent of Algerian and Moroccan Berber varieties than of Tuareg or Ghadames. 


\section{Abbreviations}

$\begin{array}{clcl}1,2,3 & \text { first, second, third person } & \mathrm{VN} & \text { verbal noun } \\ \mathrm{sg} & \text { singular } & \mathrm{C} & \text { consonant } \\ \mathrm{pl} & \text { plural } & \mathrm{V} & \text { vowel } \\ \mathrm{M} & \text { masculine } & \mathrm{cp} & \text { compare } \\ \mathrm{F} & \text { feminine } & \text { id } & \text { idem } \\ \mathrm{DO} & \text { direct object } & \mathrm{ms} & \text { manuscript } \\ \text { RES } & \text { resultative } & \text { p.c. } & \text { personal communication }\end{array}$

\section{References}

Beguinot, Francesco. 1942. Il berbero nefûsi di Fassâțo: grammatica, testi raccolti dalla viva voce, vocabolarietti. 2nd ed. Roma: Instituto per l'Oriente.

Benamara, H. 2013. Dictionnaire Amazighe - Français. Parler de Figuig et ses régions. Rabat: IRCAM.

Boudot-Lamotte, Antoine. 1964. Notes ethnographiques et linguistiques sur le parler berbère de Timimoun. Journal Asiatique CCLII. 487-558.

Bricchetti-Robecchi, Luigi. 1889. Sul dialetto di Siuwah. Comptes rendus de l'Académie des Lincei 5(4).

Brugnatelli, Vermondo. 1993. Quelques particularités des pronoms en berbère du nord. In Drouin Jeannine \& Arlette Roth (eds.) A la croisée des études libyco-berbères. Mélanges offerts à Paulette Galand-Pernet et Lionel Galand. Paris: Geunther. 229-245.

Caillaud, Frédéric. 1826. Voyage a Méroé, au fleuve blanc, au delà de Fâzoql dans le midi du royaume de Sennâr, à Syouah et dans cinq autres oasis ; fait dans les années 1819, 1820, 1821 et 1822. Vol. 1. Imprimerie royale.

Delheure, J. 1987. Agerraw $n$ iwalen teggargarent-tarumit / Dictionnaire ouargli-français. Paris: SELAF.

El Hannouche, J. 2008. Ghomara Berber. A brief grammatical survey. Leiden University M.A. Thesis.

Heath, Jeffrey. 2005. A Grammar of Tamashek (Tuareg of Mali). Berlin-New York: Mouton de Gruyter.

Heath, Jeffrey. 2006. Dictionnaire touareg du Mali. Tamachek-anglais-français. Paris: Karthala.

Hinds, Martin \& El-Said Badawi. 1986. A Dictionary of Egyptian Arabic: Arabic-English. Beirut: Librairie du Liban.

Kossmann, Maarten. 1997. Grammaire du parler berbère de Figuig. Paris-Louvain: Peeters.

Kossmann, Maarten. 1999. Essai sur la phonologie du proto-berbère. Köln: Rüdiger Köppe Verlag.

Kossmann, Maarten. 2001. The Origin of the Glottal Stop in Zenaga and its Reflexes in the other Berber Languages. Afrika und Übersee 84. 61-100.

Kossmann, M. (2011) A Grammar of Ayer Tuareg (Niger). Köln: Rüdiger Köppe Verlag. 
Lanfry, J. 1973. Ghadamès II: Glossaire (parler des Ayt Waziten). Fort-National (Algérie): Le Fichier Périodique.

Laoust, Émile. (1931) Siwa. (Publications de l'Institut Des Hautes-Études Marocaines 22). Paris: Librairie Ernest Leroux.

Minutoli, Heinrich Carl Menu von. 1827. Nachträge zu meinem Werke, betitelt: Reise zum Tempel des Jupiter Ammon in der Libyschen Wüste und nach Ober-Aegypten in den Jahren 1820 und 1821. Berlin: Maurer.

Mourigh, K. (forthcoming) A Grammar of Ghomara Berber. Leiden University PhD Thesis.

Naït-Zerrad, Kamal. 2002. Dictionnaire des racines berbères (formes attestées). Vol. 3. D-Gcy. (SELAF no. 398). Paris: Peeters.

Naumann, Christfried. 2012. Acoustically Based Phonemics of Siwi (Berber). Köln: Rüdiger Köppe Verlag.

Naumann, Christfried. (ms) Siwi-English-Arabic Dictionary.

Oussikoum, Bennasser. 2013. Dictionnaire Amazighe - Français. Le parler des Ayt Wirra, Moyen Atlas - Maroc. Rabat: IRCAM.

Pacho, Jean-Raimond. 1979. Relation d'un voyage dans la Marmarique, la Cyrénaïque et les oasis d'Audjelah et de Maradeh. (Études Libyennes no. 1). Marseille: Jeanne Laffitte.

Paradisi, Umberto. 1960a. Il berbero di Augila. Materiale lessicale. Rivista degli Studi Orientali 35. 156-177.

Paradisi, Umberto. 1960b. Testi berberi di Augila (Cirenaica). Annali N.S. 10. 43-91.

Paradisi, Umberto. 1963. Il linguaggio berbero di El-Fóqăha (Fezzân). Annali N.S. 13. 93-126.

Prasse, Karl-G. 1974. Manuel de grammaire touarègue (tăhăggart). Vol. IV-V: nom. Copenhague: Akademisk Forlag.

Prasse, Karl-G. 1990. New Light on the Origin of the Tuareg Vowels E and O. In Hans G. Mukarovsky (ed.) Proceedings of the Fifth International Hamito-Semitic Congress. Vol. I: Hamito-Semitic, Berber, Chadic. Vienna: AfroPub. 163-170.

Prasse, Karl-G. 2010. Tuareg Elementary Course (Tahăggart). Köln: Rüdiger Köppe Verlag.

Prasse, Karl-G, Ghoubeïd Alojaly \& Ghabdouane Mohamed. 2003. Dictionnaire touareg-français. Ălqamus Tămažzq-Tăfrănsist. Copenhague: Museum Tusculanum Press

Provasi, Elio. 1973. Testi berberi di Žâdo (Tripolitania). Annali dell'Istituto Orientale di Napoli 23. 501-530.

Putten, Marjin van. 2014. A Grammar of Awjila Berber (Libya). Based on Paradisi's Work. Köln: Rüdiger Köppe Verlag.

Putten, Marjin van. 2016. The origin of the front vowel nominal prefixes in Berber. Forthcoming in Zeitschrift der Deutschen Morgenländischen Gesellschaft 166(1). 11-39.

Ritter, Hans. 2009. Wörterbuch zur Sprache und Kultur der Twareg: 2. Deutsch-Twareg. Wiesbaden: Harrassowitz.

Sarnelli, Tommaso. 1924. Il dialetto berbero di Sokna. Materiali lessicali, testi manoscritti in caratteri arabi, con trascrizione e traduzione. Napoli: Società Africana d'Italia.

Sigwarth, G. n.d. Le Palmier à Djanet. Etude linguistique. Institut de recherches sahariennes de l'Université d'Alger. Monographies régionales, $\mathrm{n}^{\circ} 1$. Algiers : Imbert.

Souag, Lameen. 2009. Siwa and its significance for Arabic dialectology. Zeitschrift für Arabische Linguistik 51: 51-75.

Souag, Lameen. 2013. Berber and Arabic in Siwa (Egypt). A Study in Linguistic Contact. Köln: Rüdiger Köppe Verlag. 
Souag, Lameen. n.d. Siwi Lexicon. unpublished MS.

Stanley, Charles. V. B. 1912. The Siwan Language and Vocabulary, Proper Names, Siwan Money,

Weights and Measures (Continued from the Journal of April, 1912.). Journal of the Royal African Society 11(44). 438-457.

St. John, Bayle. 1849. Adventures in the Libyan Desert and the Oasis of Jupiter Ammon. London: John Murray.

Taine-Cheikh, Catherine. 2008. Dictionnaire zénaga-français. Köln: Rüdiger Köpper Verlag.

Walker, W. Seymour. 1921. The Siwi Language: A Short Grammar of the Siwi Language, with a Map and Ten Appendices, Including a Brief Account of the Customs, Etc., of the Siwani, Together with a Description of the Oasis of Siwa. London: Kegan Paul, Trench, Trubner.

Vycichl, Werner. 1981. Die Konstruktion des Genitivs im Berberischen der Oase Siwa. In Inge Hofmann (ed.), Festschrift zum 60. Geburtstag von P. Anton Vorbichler. I. Teil. Wien: Institut für Afrikanistik und Ägyptologie der Universität Wien. 175-183.

Vycichl, Werner. 2005. Berberstudien \& A Sketch of Siwi Berber (Egypt). In Ibriszimow, Dymitr \& Maarten Kossmann (eds). Köln: Rüdiger Köppe Verlag.

Marjin van Putten marijnvanputten@gmail.com

Lameen Souag lameen@gmail.com
Submitted: 25 Mar 15

Accepted: 21 July 15

Revisions: 20 Aug 15 